\section{Case Reports in Dermatology}

Case Rep Dermatol 2017;9:35-39

DOI: $10.1159 / 000471787$

Published online: June 8,2017

2017

This article is licensed under the Creative Commons Attribution-NonCommercial 4.0 International License (CC BY-NC) (http://www.karger.com/Services/OpenAccessLicense). Usage and distribution for commercial purposes requires written permission.

\title{
Eruptive Seborrheic Keratoses Restricted to Plaque/Patch-Stage Mycosis Fungoides
}

\author{
Eve Lebas $^{a} \quad$ Pascale Quatresooz $^{b} \quad$ Jorge E. Arrese ${ }^{b} \quad$ Arjen F. Nikkels $^{a}$ \\ ${ }^{a}$ Department of Dermatology, CHU Sart Tilman, University of Liège, Liège, Belgium; \\ ${ }^{b}$ Department of Dermatopathology, CHU Sart Tilman, University of Liège, Liège, Belgium
}

\section{Keywords}

Primary cutaneous NK and T-cell lymphoma $\cdot$ Seborrheic keratoses $\cdot$ Mycosis fungoides

\begin{abstract}
Eruptive seborrheic keratoses (ESK) are rare in dermatology. They are usually inflammatory in nature and may be encountered as Leser-Trélat sign. ESK may also be simultaneously observed with hepatic angiomas, chemotherapy, segmental neurofibromatosis, HIV or erythrodermic pityriasis rubra pilaris, psoriasis, and drug eruption. ESK may be transient and selfhealing. Others recede after successful treatment of the underlying disease. In some instances, seborrheic keratoses may follow an isotopic response and remain strictly restricted to sites of previous eczema, photo-exposition or tattoos. A patient with patch/plaque lesions of classic-type mycosis fungoides (MF) presented sudden ESK that were exclusively limited to the MF lesions. In conclusion, this patient combined an isotopic response and ESK.
\end{abstract}

(C) 2017 The Author(s)

Published by S. Karger AG, Basel

\section{Introduction}

The most frequent type of eruptive seborrheic keratoses (ESK) is the Leser-Trélat sign, a paraneoplastic dermatosis characterized by the rapid appearance of multiple, often pruritic and inflammatory seborrheic keratoses (SK) in a symmetrical pattern on the back, mimick- 
ing a Christmas tree [1]. Occasionally, ESK can be observed simultaneously with chemotherapy [2], segmental neurofibromatosis [3], HIV [4], or erythrodermic forms of pityriasis rubra pilaris [5], psoriasis, and drug eruptions [6]. They may be transient and present selfresolution. Others recede after a successful treatment of the underlying disease [6].

Furthermore, SK may remain restricted to sites of previous eczema and tattoos [7]. Wolf's isotopic response is a subtype of the Köbner phenomenon, in which one skin disorder occurs at the site of a second one [8].

\section{Case Report}

A 77-year-old male patient had suffered for several years from classic-type mycosis fungoides (MF). Two biopsies confirmed the clinical suspicion, immunohistochemistry revealed CD3, CD4 but no CD8+ atypical lymphocytes. Monoclonal TCR rearrangement was evidenced. An internal workup including a PET scan was unremarkable. Lymphocyte typing was normal. No circulating Sezary cells were observed. His usual medication consisted of metformin, atronase nasal spray, losartan, simvastatin, and gliclazide. He never presented remarkable lymphadenopathies.

Previous treatments included topical steroids inducing short remission periods. Subsequently, the patient underwent UVB and PUVA light therapies with longer complete remission periods. Due to progressive resistance to light therapies, a treatment with oral methotrexate was initiated at $20 \mathrm{mg} /$ week. After a nearly complete remission, the dosing regimen was further reduced to $12.5 \mathrm{mg} /$ week. Currently, the patient is staged as T2N0M0B0 disease.

Unexpectedly, he suddenly presented an appearance of several wart-like lesions, but only restricted to the center or the periphery of MF skin lesions (Fig. 1). The lesions were asymptomatic, nonpruritic, small, unique, and around 10 lesions were identified. At the time of diagnosis, his mSWAT score was 45 and the disease stage T2N0M0B0. A skin biopsy was performed under local anesthesia and revealed papillomatous hyperplasia, compatible with SK of the acanthotic and hyperkeratotic type (Fig. 2). An immunohistochemical search for human papilloma virus (HPV) antigens was negative and in situ hybridization for low-risk and high-risk HPV was also negative. Further skin examination did not reveal the presence of other SK outside the patch/plaque MF lesions.

Although initially not symptomatic, the progressive growth of the lesions incited to use topical cryotherapy that was successful after 2 monthly sessions.

\section{Discussion}

The sudden appearance of single SK restricted to the center or the periphery of patch/plaque-stage MF lesions has, as far as we are aware of, not been reported previously. Several hypotheses could be advanced for this special type of ESK. It is currently not known whether ESK are of a particular SK subtype [1].

First, this manifestation could represent a particular form of MF, similar to MF with unusual epidermal hyperplasia [9]. However, histology did not reveal the presence of atypical T-cells in the SK. On the other hand, ESK could be an adverse effect of methotrexate, although this was never reported previously. In contrast, methotrexate has been described as rather beneficial against SK [10]. 
Another possibility is an increased infectious risk of MF-affected skin. Indeed, as MF lesions progressively change their immunological profile from a Th1 to a Th2 profile, the risk of microbial infestations increases, in particular bacterial and viral infections [11]. In fact, longstanding MF has been demonstrated to be prone to high-risk HPV, retrieved several times over longer time periods. The presence of high-risk HPV was also demonstrated using nested PCR in verrucae occurring in 3 patients with MF [12]. However, in our case, no HPV DNA was retrieved by PCR.

Paracrine promotion of SK growth might have been induced by the MF lesion. Indeed, genetic evidence suggests that SK may be induced by a combination of both growthpromoting mutation and an additional stromal paracrine promotion [13].

The Leser-Trélat sign with rapid-growing SK has been described in only 3 patients with MF $[13,14]$. In 1 patient, ESK preceded the appearance of MF for several weeks. PUVA therapy was a successful treatment and coincided with the healing of ESK [14]. In our case with ESK, the diagnosis of Leser-Trélat cannot be excluded, particularly in the light of the underlying MF.

Exceptionally, ESK may remain strictly localized to a specific skin site, such as a decorative tattoo [7]. Furthermore, ESK can be reversible, as has been described after the healing of the underlying dermatoses [6].

Another hypothesis is that SK could induce the MF lesions, like a Köbner phenomenon $[15,16]$. However, the MF lesions in our case were present long before the appearance of the SK.

In conclusion, ESK restricted to MF lesions is a not previously mentioned phenomenon, probably linked to a Th2 environment of the MF lesions favoring the growth of ESK, just as observed with viral warts.

\section{Statement of Ethics}

Ethical approval has been obtained.

\section{Disclosure Statement}

The authors declare no competing interests. There was no funding for this work.

\section{References}

1 Jackson JM, Alexis A, Berman B, Berson DS, Taylor S, Weiss JS: Current understanding of seborrheic keratosis: prevalence, etiology, clinical presentation, diagnosis, and management. J Drugs Dermatol 2015;14:1119-1125.

-2 Lilly E, Granter SR, Haynes HA, Ibrahimi OA: Chemotherapy-induced inflammatory seborrheic keratoses in a man with acute myeloid leukemia: a variant of Leser-Trélat sign? Cutis 2012;90:235236.

-3 Takci Z, Simsek GG, Tekin O: A segmental neurofibromatosis case with eruptive seborrheic keratoses. J Pak Med Assoc 2012;62:960-962.

4 Inamadar AC, Palit A: Eruptive seborrhoeic keratosis in human immunodeficiency virus infection: a coincidence or "the sign of Leser-Trélat"? Br J Dermatol 2003;149:435-436.

-5 Gleeson CM, Chan I, Griffiths WA, Bunker CB: Eruptive seborrhoeic keratoses associated with erythrodermic pityriasis rubra pilaris. J Eur Acad Dermatol Venereol 2009;23:217-218. 


\section{Case Reports in Dermatology}

\begin{tabular}{l|l}
\hline Case Rep Dermatol 2017;9:35-39 \\
\hline DOI: $10.1159 / 000471787$ & $\begin{array}{l}\text { C } 2017 \text { The Author(s). Published by S. Karger AG, Basel } \\
\text { www.karger.com/cde }\end{array}$ \\
\hline
\end{tabular}

Lebas et al.: Eruptive Seborrheic Keratoses Restricted to Plaque/Patch-Stage Mycosis Fungoides

-6 Flugman SL, McClain SA, Clark RA: Transient eruptive seborrheic keratoses associated with erythrodermic psoriasis and erythrodermic drug eruption: report of two cases. J Am Acad Dermatol 2001;45(6 suppl):S212-S214.

7 Nicolle E, Bessis D, Guilhou JJ: Seborrheic keratosis erupting in a tattoo. Ann Dermatol Venereol 1998;125:261-263.

-8 Kroth J, Tischer J, Samtleben W, Weiss C, Ruzicka T, Wollenberg A: Isotopic response, Köbner phenomenon and Renbök phenomenon following herpes zoster. J Dermatol 2011;38:1058-1061.

-9 Puig L, Musulén E, Fernández-Figueras MT, Miralles J, Sitjas D, De Moragas JM: Mycosis fungoides associated with unusual epidermal hyperplasia. Clin Exp Dermatol 1996;21:61-64.

10 Seyfer SJ, Duvic M: Disappearance of seborrheic keratoses following treatment with methotrexate. Cutis 2013;92:E2-E3.

11 Lebas E, Arrese JE, Nikkels AF: Risk factors for skin infections in mycosis fungoides. Dermatology 2016;232:731-737.

12 Vidulich KA, Rady PL, He Q, Tyring SK, Duvic M: Detection of high-risk human papillomaviruses in verrucae of patients with mycosis fungoides and Sézary syndrome: a case series. Int J Dermatol 2009;48:598-602.

13 Duperret EK, Oh SJ, McNeal A, Prouty SM, Ridky TW: Activating FGFR3 mutations cause mild hyperplasia in human skin, but are insufficient to drive benign or malignant skin tumors. Cell Cycle 2014;13:1551-1559.

14 Miyako F, Dekio S, Tamura H, Yamada Y, Miyata N, Jidoi J, Tohgi K: Mycosis fungoides with Leser-Trélat sign: the first report of a patient from Japan. J Dermatol 1994;21:189-193.

-15 Toonstra J, Ramselaar CG, van der Putte SC: Leser-Trélat sign in mycosis fungoides. A further case report. Dermatologica 1985;171:247-249.

16 Lebas E, Libon F, Nikkels AF: Koebner phenomenon and mycosis fungoides. Case Rep Dermatol 2015;7:287-291.

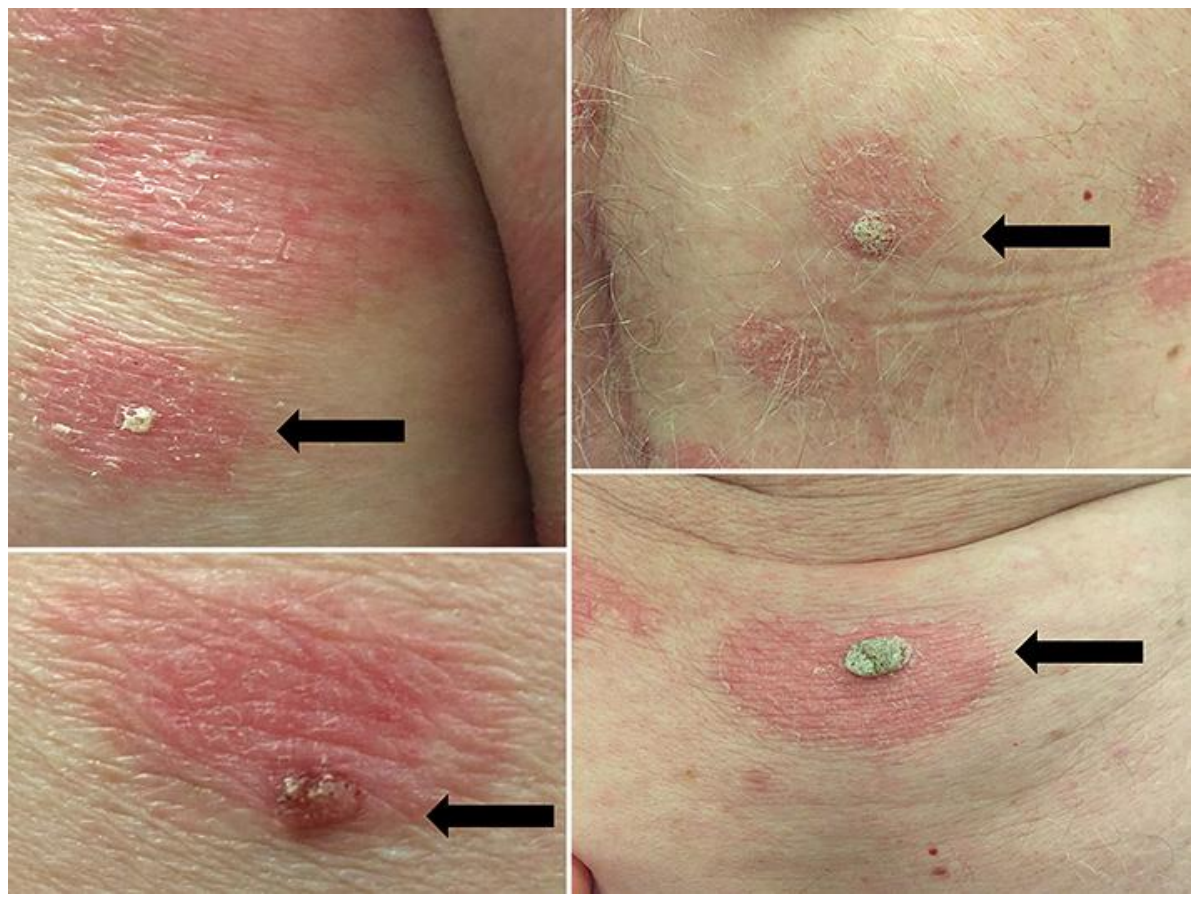

Fig. 1. Eruptive seborrheic keratoses centered in mycosis fungoides skin lesions (black arrows). 


\section{Case Reports in \\ Dermatology}

Case Rep Dermatol 2017;9:35-39

\begin{tabular}{l|l}
\hline DOI: 10.1159/000471787 & $\begin{array}{l}\text { (c) } 2017 \text { The Author(s). Published by S. Karger AG, Basel } \\
\text { www.karger.com/cde }\end{array}$ \\
\hline
\end{tabular}

Lebas et al.: Eruptive Seborrheic Keratoses Restricted to Plaque/Patch-Stage Mycosis Fungoides

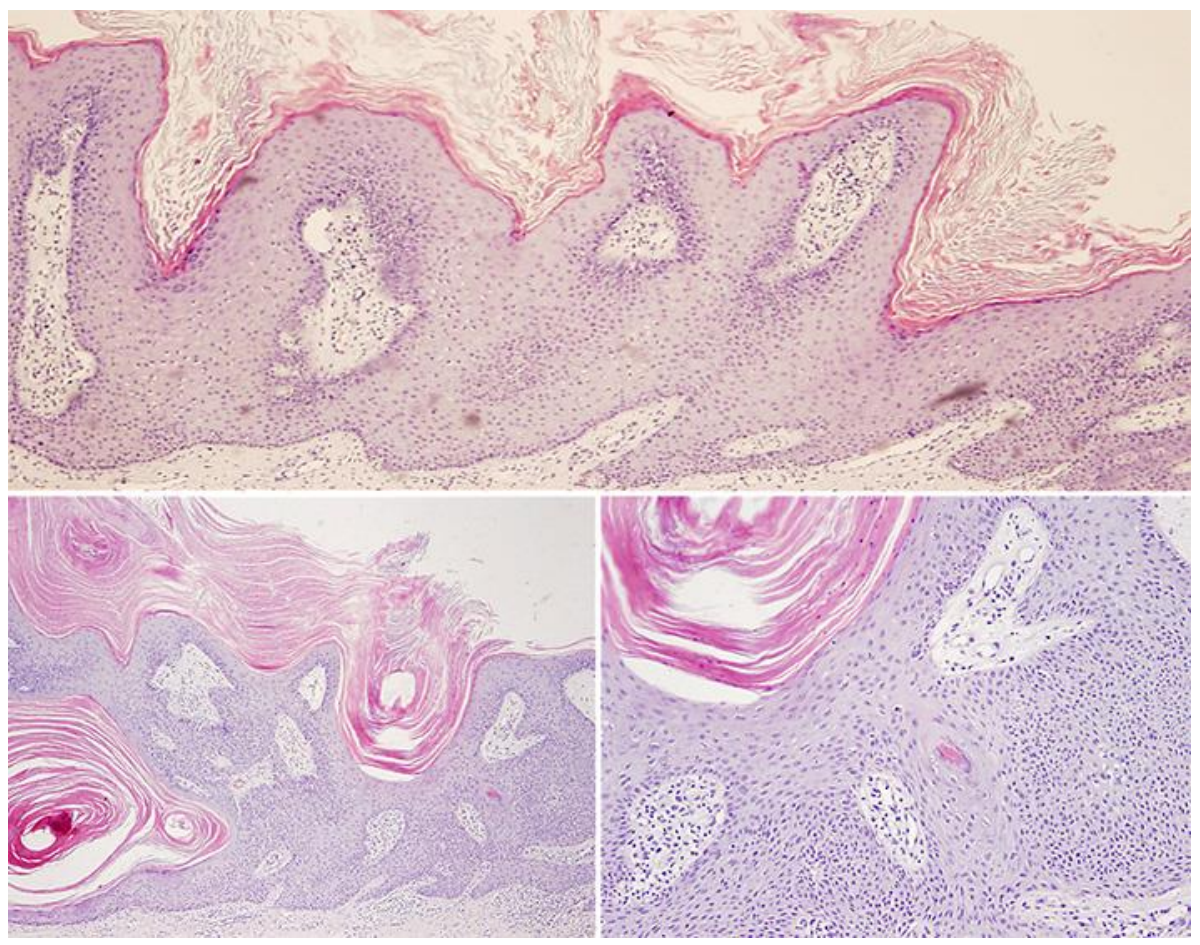

Fig. 2. Histological presentation of the seborrheic keratosis. Note the absence of atypical lymphocyte infiltration. 